\title{
The Question of National Security, and the Sustainability of the Development of Nigerian's North-East, Geo-Political Zone.
}

\author{
Ebuara, V. O. ${ }^{1}$, Sunday E.N. Ebaye ${ }^{2, *}$ \\ ${ }^{I}$ Department of educational administration and planning university of calabar, calabar-nigeria \\ ${ }^{2}$ Peace and conflict unit, general studies, cross river university of technology, calabar, cross river state, Nigeria \\ *Corresponding Author: Sunday E.N. Ebaye, Peace and conflict unit, general studies, cross River \\ University of technology, calabar, cross river state, Nigeria

\begin{abstract}
This study focused on examining the question of national security for sustainable development of the North-East geo-political Zone of Nigeria. Security of life and property has been recognized by scholars as the primary condition for progress and sustainable development of any society. This study therefore examined the necessity for the existence of economic security, environmental security and personal security as variables for national security. Three research hypotheses were formulated to guide the study while Five hundred residents of the North-East Zone of Nigeria were sampled at random but with equal representation across the most volatile states of the zone, for the study. Thirty (30) items researcher developed questionnaire was validated by experts, tested for reliability and used to collect data from residents. The data collected from the sample were subjected to statistical analysis using Pearson Product Moment Correlation analysis. Findings revealed that there is a significant relationship between national security and sustainable development. Consequently the study recommend that more emphases should be placed on a comprehensive approach to security issues in the affected areas through the formulation and enactment of a national security policy for sustainable development in the North-East geo-political zone of Nigeria.
\end{abstract}

Keywords: National Security, Sustainable Development, North-East, Geo-Political Zone.

\section{INTRODUCTION}

Nigeria as a nation has been characterized by crises and conflict among sectional and religious fundamentalist groups, resulting in loss of lives and properties. The problem of insecurity exists in different forms of criminal activities such as terrorism, kidnapping, armed attacks, suicide bombing and several other dastardly acts of arson against the innocent public. There has been great concern with the inability of the state and national government to successfully combat these insurgencies due to lack of trust arising from the existence of ethnic nationalities in the state. The incessant ethnic and religious crises in the North-East geo-political zone of Nigeria in particular are direct results of intolerance of the different groups, among which are the Jama Atu, Ahlis Sunnah Ladela' a worth, Wai-Jihad, Islamic fundamentalist groups, the Boko-Haram, etc. the sect, which is predominantly based in the North-East zone has an ideology that is repugnant to Western education and its dogma (Tor-Anylin, 2013).

The existence of these several unwanted crises has created a major problem of national insecurity leading to instability and lack of sustainable development of the affected communities. Succinctly, we can infer from the above scenario that without security, there cannot be any sustainable development; the type that meets the needs of the common people, emphasizing environmental, social and economic concerns, as well as changing the processes of life and ensuring national security, economic development and the basic quality of life for all people (Adefisan, 2014). That is why in Nigeria today according to Adejo (2012) there are contentions as to whether our system of national security is functioning effectively or not.

A number of public analyst such as Morgan (2014), Kayode (2013) and Aliyu (2012), expressed their opinion that not much is being done to combat crime and create a conducive environment for sustainable development in the face of our resources being increased actually for national security and peace to thrive in other countries of the world. The importance attached to security should be re- 
The Question of National Security, and the Sustainability of the Development of Nigerian's North-East, Geo-Political Zone.

emphasized and put into practice. This has been emphasized in the Nigerian constitution of 1999 as severally amended. Thus, section 14(2) (b) of the constitution clearly states that the security and welfare of the people shall be the primary purpose of government. By implication therefore, the constitution has task the government with the responsibility of protecting the lives, property, and welfare of Nigerians against internal and external threats and aggression. To this end, Adefisan (2014) added that it is the responsibility of the government to protect the state resources, cultural integrity, territory, sovereignty and lawful institutions.

According to Aliyu (2012), the environment in which peace and security pre-dominate and in which human dignity and human rights are recognized in its subject matter and content, sustainable development becomes imperative particularly to ensure better livelihood of the citizen.

\section{Statement of the Problem}

The ever huge investment in national security is being matched by an equally very keen interest in sustainable development of the nation. Based on the premise that the imperativeness of national security is to provide a conducive environment in which human dignity and human rights are protected and recognized, where there is no danger of insurgencies, political pressure or economic coercion so that the society can developed and progress freely.

In the contemporary Nigeria, particularly in the North-East geo-political zone, national security for peace building and sustainable development has eluded the entire area due to the absence of peace, just and equitable living conditions.

The inability of the Nigerian government to put a stop to the unprecedented level of insecurity such as communal violence, terrorism, kidnapping and hostage taking, Sharia crisis, religious intolerance/ violence, bomb explosions that have been on the increase leading to enormous lost of lives, properties and a general atmosphere of siege and social tension on the people has affected the peace and sustainable development of the North-East zone of the country. It is quite obvious that in the face of these challenges, sustainable development cannot take place and the progress of the area will remain largely unachievable. It appears that there is something culpably wrong with the government management and administration of the zone comprising -Bornu, Adamawa and Yobe. The observation is that national security and peace are yet to be seriously emphasized and properly addressed.

At this juncture, the search for national security, peace and sustainable development has become imperative and therefore need to urgently be given the adequate attention it deserve.

\section{THEORETICAL FRAMEWORK}

The theoretical postulations used to explicate this study include the biological and Psychological, and the frustration and aggression theory. Certainly an eclectic approach, based on their methodological and exploratory powers.

The biological and Psychological theory; with scholars such as Abraham Maslow (1954 \&1970), Edwin O. Wilson (1975), David P. Barash (1977), Robert C. North (1977), Arthur L. Caplan (1978), etc. argue that much of the political and economic competitions and conflicts among human societies are traceable to the fact that the demand for things required to satisfy our needs always exceeds the supply.

The frustration and aggression theories with Scholars such as John Dollard (1939), Leonard Berkowitz (1962), Aubrey Yates (1962), among others, argue that people have basic needs such as food, shelter, security, etc, which if not fulfill can cause frustration thereby leading to aggression and conflict(s). (Dougherty \& Pfaltzgraff, 1977). They posit that aggression/conflict is the outcome of frustration which arises when individual desires are denied as a result of the way the society is structured.

These theoretical postulations/arguments find relevance in our study as the volatile/revolutionary nature of the North-East geo-political zone of Nigeria against established institutions or amongst the people cannot be disassociated or un connected to the gap that exist between the very high expectations/demands of the people and the very low/limited supply of all forms of available resources. 
The Question of National Security, and the Sustainability of the Development of Nigerian's North-East, Geo-Political Zone.

\section{Purpose of The Study}

This study, focused on the questions of national security and the sustainability of the development of Nigeria North-East geo-political zone. Specifically the study intends to examine the relationship between:

- Economic security and sustainable development

- Environmental security and sustainable development

- Personal security and sustainable development.

\section{STATEMENT OF HyPOTHESES}

The following hypotheses which are constructed in the null form shall serve as tentative/working statements for this study.

- There is no significant relationship between economic security and sustainable development

- There is no significant relationship between environmental security and sustainable development.

- There is no significant relationship between personal security and sustainable development.

\section{Methodology}

The study examined the imperativeness of national security for sustainable development of NorthEast geo-political zone of Nigeria; with emphasis on the most volatile states, which include: Maiduguri, Yola and Damaturu. The study adopted a descriptive survey research design. The population of the study was drawn from inhabitants of Maidugri, Yola and Adamawa Metropolis respectively. A sample size of five hundred (500) respondents comprising male and female residents of the most in-secured North-East cities of Maidugri, Yola and Damaturu were drawn, using stratified random sampling technique. The percentage of the sample represents $40 \%$ from Maidugri, $30 \%$ from Yola and 30\% from Damaturu. However, the research design for this study was the survey design. The instrument for the study used questionnaire for data collection. Part one of the questionnaire sought information on respondents biographic/demographic data, while part two contained items that were to determine the dependence of sustainable development on national security. To determine the reliability of the instrument, a trial test was conducted using 50 members of the Area that were not included in the study samples. Their responses were collated and analyzed. The instrument yielded a co-efficient value of 0.08 which the researchers considered satisfactory for the study. The hypotheses were therefore analyzed using the Pearson Product Moment Correlation analysis.

\section{FINDINGS}

\subsection{Hypothesis 1}

There is no significant relationship between economic security and sustainable development. This hypothesis was tested using Pearson Product Moment Correlation analysis. Result of the analysis is presented in table 1 below.

Table1. Pearson Product Moment Correlation of the relationship between economic security and sustainable development.

$(\mathrm{N}=500)$

\begin{tabular}{|l|l|l|l|l|}
\hline Variable & $\sum \times$ & $\sum x^{2}$ & $\sum \times \mathbf{y}$ & r \\
\hline National security (x) & 13976 & 398136 & 188402 & $0.124^{*}$ \\
$\begin{array}{l}\text { Sustainable developing in the areas of } \\
\text { economic security (y) }\end{array}$ & 6718 & 93636 & & \\
\hline
\end{tabular}

Significant of $0.05, \mathrm{df}=498$, critical $=0.062$.

The result of the analysis in table 1 shows that the calculated r-value of 0.124 is greater than the critical r- value of 0.062 at 0.05 level of significant with 498 degrees of freedom. This means that there is a significant positive relationship between national security and sustainable development in 
The Question of National Security, and the Sustainability of the Development of Nigerian's North-East, Geo-Political Zone.

the areas of economic security. This reveal that, the more there is national economic security in the North -East zone of Nigeria, the more there will be sustainable development of the society; development that meets the needs of current generations of citizens in the area. Based on this result, the null hypothesis was rejected. The positive $r$ in the result means that the more there is economic security, the more sustainable the development of the society in meeting the basic quality of life of the people.

\subsection{Hypothesis 2}

There is no significant relationship between environmental security and sustainable development.

Table2. Pearson Product Moment Correlation analysis of the relationship between environmental security and sustainable development.

$(\mathbf{N}=\mathbf{5 0 0})$

\begin{tabular}{|l|l|l|l|l|}
\hline Variable & $\sum \times$ & $\sum x^{2}$ & $\sum \times \mathbf{y}$ & $\mathbf{r}$ \\
\hline National security (x) & 13976 & 398136 & 188402 & $0.105^{*}$ \\
$\begin{array}{l}\text { Sustainable development in the areas of economic } \\
\text { security (y) }\end{array}$ & 6640 & 92348 & & \\
\hline
\end{tabular}

Significant of $0.05, \mathrm{df}=498$, critical $\mathrm{r}=0.062$.

Result of the analysis presented in table 2 above shows that the calculated $r$-value of 0.105 is greater than the critical r- value of 1.062 at 0.05 level of significance with 498 degrees of freedom. This means that there is a significant positive relationship between national security and sustainable development with regards to environmental security. That is, the more there is environmental security of life and properties, the more development is sustained in the North-East geo-political zone of Nigeria. Based on this result; the null hypothesis was rejected. The positive $r$ in the result means that the more there is absence of threat to life, property and environmental wellbeing of the people, the more sustainable will be the aspect of development of human security with regards to environmental security.

\subsection{Hypothesis 3}

There is significant relationship between personal security and sustainable development.

Table3. Pearson Product Moment Correlation analysis of the relationship between personal security and sustainable development.

( $\mathbf{N}=\mathbf{5 0 0})$

\begin{tabular}{|l|l|l|l|l|}
\hline Variable & $\sum \times$ & $\sum x^{2}$ & $\sum \times \mathbf{y}$ & $\mathbf{r}$ \\
\hline National security (\#) & 13976 & 398136 & 188402 & $0.232^{*}$ \\
$\begin{array}{l}\text { Sustainable developing in the areas of } \\
\text { economic security (y) }\end{array}$ & 6696 & 93332 & & \\
\hline
\end{tabular}

Significant of $0.05, \mathrm{df}=498$, critical $\mathrm{r}=0.062$.

Result of analysis in table 3 shows that the calculated $r$ - value of 0.232 is greater than the critical rvalue of 0.062 at 0.05 level of significance with 498 degrees of freedom. Thus means that there is a significant positive relationship between national security and sustainable development in terms of personal security. That is, the more personal security and safety is guaranteed, the sustainability of development of the society will be ensured. Based on this result, the null hypothesis was rejected. The positive $r$ in the result means that the higher there is personal security the more there will be sustainable development of live and property.

\section{DISCUSSION OF FINDINGS}

National security threats differ in directions, dimension and imminence from state to state in Nigeria. In the geo-political zones of Nigeria, north-West, North-East, South-South, South-West, South-East, and North-Central zones, the security issues in current times have become more complex, diverse, and exceedingly mobile, more dramatic and multidimensional in character and content (Nwankwo, 2013). 
The Question of National Security, and the Sustainability of the Development of Nigerian's North-East, Geo-Political Zone.

The analysis from hypothesis one in table one revealed that there is a significant relationship between national security and sustainable development. Specifically in the area of economic security, the findings further revealed that sustainable development can be improved upon when the economic security that provides conditions of well being and freedom from the danger of not having stable income, food, wealth and maintenance of life is adequately put in place in the society.

In consonance with the above observation Rupert (2007) affirmed that sustainable development is possible when there is employment and job security, where there is a stable source of financial income that flows for the ongoing maintenance/sustenance of one's standard of living currently and in the near future.

From the foregoing, the researchers have observed that national economic security for supporting life and sustaining development have been absent in the North-East cities of Bornu, Adamawa and Yobe due to incessant crises, suicide bombing, terrorism, hostage taking, kidnapping, raping, wanton destruction of lives and property resulting in abandonment of their homes and farmlands.

The findings in the analysis of hypothesis two showed that environmental security related positively with sustainable development. The calculated $r$-value of 0.105 is by far greater when the critical $r$ value of 0.062 at 0.05 level of significance. This indicates that the more the environmental security is put in place, concerning life and property, the more development will be sustained for improved quality of life.

When the environment is insecured and unconducive for living, unpredictable and punctuated with human trafficking, armed robbery, terrorism, kidnapping and other forms of threats, sustainable human development cannot be attained (Akinboye, 2003). Akinboye further opined that an environment that experiences sustainable development promotes job-led growth rather than job-less growth. It is development that stressed empowerment, employment, equity and effective citizens, that is, citizens that are useful to themselves, to their families, communities, states and the nation. Adenipekun (2007) corroborates Akinboye's arguments based on the findings of this study when he stated that one of the underlying purposes in life is that individuals should live in secured environment and to be empowered through fulfilling their needs of existing and be able to stand on their own, become productive, prosperous and useful to themselves, their families and the community at large. Sustainable development according to Adenipekun, entails the alleviation of poverty and the maintenance of environmental and ecological equilibrium in the process of exploiting resources for the provision of jobs, income, food and social services that promote the quality of human dignity for the present and future generation.

In line with the above analysis, UNESCO (2005) states that overall in significance of sustainable development have been tackled through economic, environmental and social personal securities. The result of the analysis of hypothesis three (3) revealed that there is a relationship between national security and sustainable development in the areas of personal security and safety. In view of this revelation, it is often difficult to experiences development without personal security because security is tantamount to development. This implies that without security, there will be no sustainable development. To be candid, sustainable development is fast in a country or society where security is assured. Okeke, (2013).

Similarly, Fayeye (2011), has argued that security which implies the maturation of the structures and processes of societies required the safety and protection of individual's persons from harm and danger and from all spheres of life.

This assertion corroborate the work of Mango, Hakimi and Malhoja (2013) where they affirmed that personal security is an issue that affects development of any country. This has become imperative in the sense that personal security is a basic need of every human being since the instinct for self survival and self preservation is inbuilt on every person for sustainability. To tackle the challenges of personal security in North-East environment, there have to be individuals who are discipline and see themselves as vanguards of peace and security in the environment and uphold social justice and fair play. Personal security has become necessary for the attainment of physical and national security and overall peace and development of the nation. 
The Question of National Security, and the Sustainability of the Development of Nigerian's North-East, Geo-Political Zone.

In line with the above assertion Ojobo (2008) reinterated that for personal security to be sustained in the society, a joint-action of all concerned with high sense of communication in protecting and defending a nation's territorial integrity, values and aspirations must be pursued. To successfully maintain and enhance personal security, party depends on the individual's awareness on the best practices for affirming personal security. This is a matter of concern for all citizens and should be given adequate attention in government policies and programmes.

\section{CONCLUSION/RECOMMENDATIONS}

It is clear from the foregoing that the question of National security and the sustainability of the development of Nigeria cannot be overemphasized. Therefore any effort put in place by the government to address the problem of insecurity such as economic insecurity, environmental and personal insecurity that burdened on terrorism, kidnapping, armed robbery, human trafficking rape and arson has to be through the means and methods of re-orientating the minds of the citizenry into a proper value system as well as the context of the benefit of safety and well-being, freedom and liberty for a sustainable development of the nation. Consequently, the researchers make bold to recommend as follows.

Given the complex nature of our society and the increasing wave of crimes which has prevailed over time in the North-East of Nigeria, community leaders, parents and concerned citizens must liaised with the Nigerian army, police force, state security services, Nigerian security and civil defence corps, including private security agencies to combat/prevent the re-occurrence of terrorism and other forms of threats to people in the area.

As a remedial measure, there is need for a temporal closure of the nation's borders particularly in the affected areas so as to check the influx of immigrants insurgencies into the country.

There is need for a participatory/collaborative approach to the fight against insurgencies in the country. Emphases must be placed on a comprehensive approach to security issues/ values in the affected areas through the formulation and enactment of a national security policy in order to ensure greater sustainable development in the North-East geo-political zone in particular and the Nigeriastate at large.

\section{REFERENCES}

[1] Adefisan, A.K. (2014). How Peace Education could Promote National Security in Nigeria, Journal of Education 2(12)1-10.

[2] Adejo, O. (2012). Management Issues in Education: Aboki Publishers, Makurdi, Nigeria.

[3] Adenipekun, T.U. (2007). An overview of conflict management and resolution, in work organization Ibadan: Government Press.

[4] Akinboye, K. O. (2003). The Roles of National Security for Peace and Sustainable Development in Nigeria. Journal of Humanities and Social Science 3(6)2.

[5] Aliyu, B.M. (2012). The search for national security in Nigeria: Challenges and prospects. Lagos: Government Press.

[6] Dougherty, J. E and Pfaltzgraff, Jr. R.L. (1997). Contending theories of International Relations: A comprehensive survey, New York: Adison Wesley Longman Publisher.

[7] Fayeye, S.N. (2011). Pathways towards Managing Personal Safety and Security in Nigerian Communities Ilorin: Faye Press.

[8] Kayoed, O. (2013). Corruption and National Security in Nigeria: The role of the media commentary.

[9] Mango, S.D. Hakimi, M.W. \& Maihoja, A.M. (2013). In Ayeni A.O.Emetarom, U. G. Abdulkoreem A.Y. Undie 3. A., \& Okon J.E. (2013) (Eds) managing Educaion for National Security.

[10] Morgan C.O. (2014). Security challenges in Nigerian environment, Heints: Allyn \& Bacon Publishers.

[11]Nwankwo, J.L. (2013). Managing Education for National Security: Keynote Address. MEAP Conference 2013 publications.

[12] Ojobo, F.N. (2008). Personal Safety and Security. Retrieved from http/www.stategov./documents/ organization/1978pdf.

[13] Okeke, A. (2013). National Security and the Development of Nigeria Society for sustainability Enugu: Nwani Press. 
The Question of National Security, and the Sustainability of the Development of Nigerian's North-East, Geo-Political Zone.

[14] Rupert, M. (2007). Managing Education for Economic security http/www./crc/org/what.we-do/ ensuring economicsecurity/index./sp.Retrieved19/08/15.

[15] Tor -Anylin,T (2013). Critical strategies for achieving effective efficient management of education for national security. Lead paper; presented at NEAP conference.

[16] UNESCO (2005). Education webmaster. World conference on education framework and action $4^{\text {th }}$ October 2003.

Citation: Ebuara, V. O., Sunday E.N. Ebaye. "The Question of National Security, and the Sustainability of the Development of Nigerian's North-East, Geo-Political Zone." International Journal of Political Science (IJPS), vol 4, no.1, 2018, pp. 1-7. doi: http://dx.doi.org/10.20431/2454-9452.0401001.

Copyright: () 2018 Authors. This is an open-access article distributed under the terms of the Creative Commons Attribution License, which permits unrestricted use, distribution, and reproduction in any medium, provided the original author and source are credited. 